\title{
George Sand, Flavie
}

\section{Lise Sabourin}

\section{(2) OpenEdition}

\section{Journals}

\section{Édition électronique}

URL : http://journals.openedition.org/studifrancesi/9290

DOI : 10.4000/studifrancesi.9290

ISSN : 2427-5856

\section{Éditeur}

Rosenberg \& Sellier

\section{Édition imprimée}

Date de publication : 1 juin 2008

Pagination : 209-210

ISSN : 0039-2944

\section{Référence électronique}

Lise Sabourin, "George Sand, Flavie », Studi Francesi [En ligne], 154 (LII | I) | 2008, mis en ligne le 30 novembre 2015, consulté le 07 janvier 2021. URL : http://journals.openedition.org/studifrancesi/9290 ; DOI : https://doi.org/ERREUR PDO dans /localdata/www-bin/Core/Core/Db/Db.class.php L.34: SQLSTATE[HY000] [2006] MySQL server has gone away

Ce document a été généré automatiquement le 7 janvier 2021.

\section{(c) (i) () $९$}

Studi Francesi è distribuita con Licenza Creative Commons Attribuzione - Non commerciale - Non opere derivate 4.0 Internazionale. 


\title{
George Sand, Flavie
}

\author{
Lise Sabourin
}

\section{RÉFÉRENCE}

GEORGE SAND, Flavie, présentée par Danielle BAHIAOUI, [7 square Dunois 75646] Paris

[Cedex 15], «Le Jardin d'essai», 2006, pp. 103.

1 La «nouvelle» épistolaire, comme la qualifiait parfois Sand, Flavie, parue en 1859 et publiée récemment en Ukraine par un francophile ardent, fait l'objet d'une réédition utile par Danielle Bahiaoui, qui l'encadre d'une introduction (pp.5-14) et d'une postface-conclusion (pp. 95-102).

Les huit chapitres correspondent chacun à une lettre, plus ou moins longue: cinq de l'hérö̈ne éponyme à son amie de couvent, Robertine, une de sa correspondante, les deux autres des hommes considérés dans la question de son mariage, Malcom, le séduisant fiancé envisagé par sa famille, et le savant Emilius, austère au premier abord pour cette ingénue jouant les cyniques, qu'elle finira pourtant par lui préférer. George Sand s'amuse visiblement à faire de ce journal humoristique, léger et plein de quiproquos, une réflexion sur «la surprise de l'amour» qui attend la jeunesse coquette et frivole. En effet, à l'époque où elle écrit, la bonne dame de Nohant est entourée de ses enfants à marier: Maurice partage la complicité de Malcom avec sa mère et sa passion des papillons; Solange a quelque chose de Flavie, quoique cette «fauvette» sympathique puisse sembler plutôt prémonitoire de la «Diavolina», Lina Calamatta. La romancière y glisse aussi quelques détails autobiographiques répartis entre la figure maternelle de lady Rosemonde, et celle de sa fille, qui n'est pas sans rappeler les réactions d'Aurore retrouvant Nohant à 17 ans.

3 Sand se fait en réalité «l'écho d'un quotidien immédiat et d'une très lointaine et primordiale blessure» (p. 102), ce qui donne tout son intérêt à la lecture de ce tendre «petit roman». 